\title{
Selling Authorization Legal Agreement Status Will Be Weighed Against Collateral Mortgage (Case Study PT. Bank Tabungan Negara (Persero) Tbk.)
}

\author{
Rian Dwi Anggoro ${ }^{1}$ and Umar Ma'ruf ${ }^{2}$
}

\begin{abstract}
This study aims to determine why the binding of collateral in the process of granting subsidized housing loans in PT. Bank Tabungan Negara (Persero) Tbk. Pekalongan branch office is not binding perfectly implemented using the security rights, the legal position of the agreement of power sold to the collateral to be encumbered encumbrance in the process of providing subsidized credit facilities, and a form of legal protection for authorizing the use of certificate authority to sell. This study uses empirical juridical approach or Socio Legal Research. Data collected through literature, observation and interviews. The survey results revealed that the cause of non-performance perfect binding manner using the right mortgage loan process dala subsidized home ownership in PT. Bank Tabungan Negara (Persero) Tbk. Pekalongan branch office is due to the type of housing loan subsidies are certain types of loans are regulated in the legislation which the binding process is limited to a power of attorney install security rights. On the basis of these reasons the bank asked the Notary / PPAT can issue certificates aimed at selling power if the debtor defaults, the creditor as the bank can make the sale to get the loan repayment. However, if the power of attorney install security rights has been upgraded to the Agreement of Encumbrances Encumbrance and has been registered to receive the certificate Encumbrance the collateral execution process should be subject to the laws Mortgage. Making the notarized agreement of power selling is a form of legal protection for the debtor as the authorizer.

Keywords: Authorization Agreement Sell; Collateral Will Be Charged Mortgage; Credit Homeownership Subsidies.
\end{abstract}

\section{Introduction}

Operations of banks in granting credit facilities is the main function of the banking business, namely the function of channeling funds to those who need it after receiving the collection of funds from the depositors depositors. ${ }^{3}$

Obtain credit from one's bank debtors must go through several stages, starting from the stage of submission of credit applications until the credit acceptance stage, after the loan application is received, then made a loan agreement between the bank and the debtor. The credit agreement is an agreement in principal (the principal) who is real, real terms here is the occurrence of a credit agreement is determined by the delivery of money by banks to debtors, in addition to the credit agreement, between banks and debtors also created security agreement or Letter of Authorization Imposing Mortgage Continued with the imposition of Mortgage, acknowledgment of debt and a power of attorney to sell.

Credit guarantees under the provisions of Article 2 (1) Decree of Directors of Bank Indonesia No. 23/69 / KEP / DIR dated February 28, 1991 on Guarantee Lending, that is the guarantee of a bank is a conviction on the ability to repay their loans in accordance with the agreement. Meanwhile, according to the provisions of Article 1, paragraph 23 of Act No. 10 Of 1998, which is an additional guarantee that collateral is submitted to the

1 Student of Master Program (S2) of Notaries Faculty of Law UNISSULA Semarang email rian.anggoro16@gmail.com

2 Lecturer of Faculty of Law UNISSULA Semarang

${ }^{3}$ Gunarto Suhardi 2003 Usaha Perbankan dalam Perspektif Hukum Yogyakarta: Kanisius p. 75 
bank debtors in the context of granting credit facilities or financing based on Islamic principles.

Generally bail is divided into two, namely the guarantee of individual (personal guaranty) and collateral material. Special material guarantee for the land is no longer used and credietverband mortgage institutions, mortgage institutions and credietverband have been revoked since the enactment of Act No. 4 of 1996 on Mortgage of Land and Their Objects Relating to Land (Mortgage).

Article 1, paragraph 1 of Act No. 4 of 1996 on Mortgage, said understanding the security rights, namely: "The right of bail imposed on land rights as stipulated in Act No. 5 of 1960 neighbor Regulation of Agrarian following or not following objects that are the one unit with the ground repayment of certain debt obligations, which gives precedence to the position of certain creditors to other creditors ".

Since the enactment of Act No. 4 of 1996 on the right of dependents, should in practice binding of bank credit to the debtors, banks are no longer prepare the agreement of power to sell, because it has no institution Mortgage, but the agreement of power sold remain available in each binding credit, arguing banks are in need of a letter agreement the power to sell, considering the use of agency encumbrance takes a long time for repayment of the loan debtors, banks tend to act more quickly and practically and cost of light, due to the lengthy process of selling security object by using the institution of mortgage, directly affecting the financial condition of the bank.

Formulation of this research is: Why in the provision of subsidized housing loans at Bank BTN Branch Pekalongan is not done perfectly binding using Encumbrance?; as well as the legal domicile certificate authority How to sell against collateral that would be burdened encumbrance?

\section{Research Methods}

Type the approach is empirical juridical approach ${ }^{4}$ In this study, in addition to using the methods of science also see the reality in the field, especially in the execution of an agreement authorized to sell the collateral to be weighed against the security rights in the provision of mortgage loans at Bank BTN Branch Pekalongan.

Based on the objectives to be achieved, this research is done Descriptive Analytical is intended to provide the data as thoroughly as possible about the people, circumstances or other symptoms ${ }^{5}$, In order to take the objective data that can show reality or the complex reality of the position of the agreement of power sold to the collateral to be encumbered encumbrance in the granting of mortgages at Bank BTN Branch Pekalongan.

Primary Data Ie data obtained directly in the field, the primary data in this paper in the form of information for the position of Attorney Selling agreement against collateral that would be burdened with security rights in the process of providing subsidized mortgages at Bank BTN Branch Pekalongan.

While the secondary data consists of: Primary Legal Materials covering the laws of the material that: Constitution of 1945,Act No. 1 of 1960 on Agrarian, Act No. 10 of 1998, Act No. 4 of 1996 on Mortgage of Land along Objects Other related to Land (UUHT), Government Regulation No. 24 of 1997 on Land Registration. Secondary Legal material that includes writings of jurists and other areas that may provide an explanation of primary legal materials. Tertiary Laws material in the form of materials obtained in addition to materials such as dictionaries law jurisprudence, Indonesian dictionary and

${ }^{4}$ Ronny Hanitijo Soemitro Metodologi Penelitian Hukum dan Jurimetri Jakarta Ghalia Indonesia 1990 p. 34

${ }^{5}$ Soerjono Soekanto Pengantar Penelitian Hukum Jakarta UI Press 1986 p. 10 
encyclopedia.

Processing is done by analyzing and linking the Book of the Civil Law, Act No. 10 of 1998, Act No. 5 of 1960 on Agrarian and Act No. 4 of 1996 on Mortgage of Land along with objects related to the Land especially the legal position Powerful Selling agreement against collateral to be encumbered encumbrance.

\section{Results And Discussion}

\subsection{Provision Of Subsidized Housing Loans At Bank BTN Branch Offices of Pekalongan Not Done Completely With Mortgage}

FLPP subsidized mortgage loan is a government subsidy program to provide home ownership financing housing with housing financing liquidity for all Indonesian people with mild installment and fixed throughout the loan period. Subsidized mortgage program is a support program for housing finance for low-income people to obtain appropriate housing that is issued by a bank executive who has been working with the Ministry of Public Works and Public Housing (Kemenpera). ${ }^{6}$ Bank Tabungan Negara (BTN) is the only bank liquidity facilities for program implementers Housing Financing (FLPP) issued by Kemenpera.

Process conducted by lending to the public BTN course closely related to the role as a Notary Public officials who have the authority to make the agreement. The Acts relating to the bank in terms of providing subsidized mortgage facilities in BTN Bank Branch Pekalongan is the recognition Debt $(\mathrm{PH})$, the credit agreement (PK), Surat Imposing Mortgage (SKMHT), and the Agreement of Authorization to Sell.

Notary does not issue the Agreement of Encumbrances Encumbrance (APHT), but only in the manufacture SKMHT, it is regulated under Article 12 Regulation of the Minister of Agriculture or the National Land Agency No. 22 of 2017 Concerning Determination Time Limit Use the Power of Attorney Imposing Mortgage to guarantee repayment certain credit. The contents of the article are:

"Power of Attorney Imposing Mortgage to guarantee repayment of credit / financing / loans apply until the expiry of the basic agreement as follows:

- Credit / Financing / Loans to customers of Micro and Small Enterprises, the scope of definition of productive enterprises owned by individuals and / or entities individuals.

- Credit / Financing / Loans intended for the procurement of housing, namely:

- Owners or core home improvement, modest houses or flats with maximum land area of $200 \mathrm{~m}^{2}$ (two hundred square meters) and a building area of not more than $70 \mathrm{~m}^{2}$ (seventy square meters); and

- Owners or repair plots Ready to Build (BCC) with an area of 54 square meters (fifty-four square meters) up to $72 \mathrm{~m}^{2}$ (seventy-two square meters) and loans to finance the building.

- Credit / Financing / Loans more productive with a ceiling up to Rp200.000.000,00 (two hundred million rupiah). "

On the condition that security object is not bound by a guarantee institution, Bank BTN Branch Pekalongan take wisdom which include the delivery of an agreement authorized to sell by the Borrower to the Bank. ${ }^{7}$

The basic goal why not do the binding assurances to the level APHT is the cost of loading

\footnotetext{
${ }^{6}$ Nikmati KPR Murah di BTN Sejahtera FLPP https://kreditgogo.com/pinjaman/KPRKPA/BTNSejahtera-FLPP-KPR.html Accessed Date February 122018

7Pieter Latumeten Kebatalan dan Degradasi Kekuatan Bukti Akta Notaris Serta Model Aktanya Makalah Kongres XX Ikatan Notaris Indonesia Surabaya 2009 p. 18.
} 
Encumbrance felt very expensive by the debtor, the author interview with Susatyo Isbandono as Head of Unit of Consumer Credit Bank BTN Branch Pekalongan obtained the data that the cost to make SKMHT to the notary / PPAT is around Rp. 200 thousand to Rp 300 thousand, while the cost of the binding guarantees up to the level APHT is Rp. 1 million up to Rp. 2 million. So that it is in line with the government's objective to provide cost relief to the people who apply for certain credits that are not burdened cost too much in getting loans from banks. ${ }^{8}$

Subsidized mortgage products distributed by BTN belongs to the type of credit in terms of SKMHT valid throughout the period of the loan period. Against the above mentioned conditions, if the debtor defaults and the lender plans to carry out rescue bad credit then the creditor must first make a collaboration with PPAT Agreement Mortgage Encumbrances based SKMHT that already exist.

The first step should be done with the upgrade SKMHT creditors become APHT up to the formation of Encumbrance is:

SKMHT
Creditor Request keNotaris / PPAT For improving SKMHT be APHT (Issuing
Mortgage)
APHT
Rotary PPAT in 7 days after the signing of the entitlements shall transmit
APHT dependents and other warkah to the Land Office
$\begin{gathered}\text { Registration APHT In BPN } \\ \text { book rights over land which is the object of mortgage and copied the notes } \\ \text { on the certificate of land rights are concerned. }\end{gathered}$
Encumbrance Certificate (SHT)
Encumbrance was born on the day of the date made encumbrance of the
land book. Publishing Encumbrance Certificate (SHT).

\subsection{Selling Authorization Legal Agreement Status Will Be Weighed Against Collateral Mortgage Credit Facility On Housing Subsidy}

BTN Bank Branch Office of Pekalongan associated with providing subsidized housing loans, bank after agreeing to a credit of the debtor will perform security object Encumbrance binding but is only limited to the manufacturing process SKMHT. Bank asks the debtor to make an agreement to sell the power that must be signed by the debtor Mortgage providers whose content aims to authorize the bank as creditor to sell or transfer ownership of their land rights if the debtor defaults.

Sales of security object Encumbrance under hand is the final step (ultimum remedium) taken as creditor banks after the approach to the debtor and the debtor to submit a letter

\footnotetext{
${ }^{8}$ Interview with Mr. Susatyo Isbandono as Head of Consumer Credit Unit on March 122018 took place at the BTN Bank Branch Pekalongan Jl. Merdeka No. 7.
} 
of voluntary submission that the object of collateral Mortgage that it has provided the bank. The use of power selling security object Encumbrance under hand more be counted by the bank, compared to using Encumbrance certificate, because by using the power of selling seen as more effective, meaning that the sale of the Mortgage security object does not require a long time and a long process. Mortgage Holders security object can directly sell the security object Encumbrance if the debtor defaults, besides that creditors will not receive claims or demands from the debtor. Sales of security object Encumbrance under hand not through an auction process, the lender does not require the execution request Mortgage security object to the District Court. In other words the bank as creditor in selling security object Encumbrance under hand does not cost execution and auction fees, and no convoluted in the conduct of the sales procedure security object such Encumbrance. ${ }^{9}$

Thus it can be said that the function of the power sold in the sale of collateral object Encumbrance under hand is to facilitate bank as creditor in carrying out the sale or transfer of land ownership is the object of collateral Mortgage to obtain repayment of its receivables from the debtor if the debtor defaults.

Article 20 (1) UUHT No. 4 of 1996 states that, "If the debtor in default, and based on a. Mortgage holders first rights to sell a security object Encumbrance as referred to in Article 6 UUHT No. 41996 or b. Executorial title contained in the Encumbrance certificate referred to in Article 14 paragraph (2) UUHT No. 4 In 1996, the object of Encumbrance sold through public auction in accordance with the procedures specified in the legislation for the settlement of accounts receivable Encumbrance certificate holders with the right mendahulu than other creditors ". Furthermore, Article 20 (2) UUHT No. 4 of 1996 states that, "In the deal providers and holders of Encumbrance, Sales Mortgage object can be executed under hand if thus it will be obtained the highest price that benefits all parties. " Article 20 (3) UUHT No. 4 of 1996 states that, "The implementation of security object Encumbrance sales under hand as referred to in paragraph (2) above can only be made after the expiration of one month since notified in writing by the provider and / or holders of Encumbrance to parties- interested parties who announced in two newspapers circulating in the area in question and / or local mass media, as well as no party raised objections ".

Notary Setiaty Solichah, Bachelor of Law and Notary Nur Sofati, Bachelor of Law explained that the power to sell does not have binding force, because in case of default of the debtor used or used to sell a security object is Encumbrance for Mortgage registered and regulated by law. Furthermore, both explained that however if the creditor will sell the security object by using the power of selling it, first the creditor request a letter of voluntary surrender of the debtor. ${ }^{10}$

According to the authors, the power to sell it does not bind or does not have the binding force for the power selling can not be registered or not an object registration. While something of loading over land rights should be registered and one is the nature of the security law is the publicity that other person or third party can know that the land rights have been pledged or encumbered with debt. Additionally creditors have preferential rights and are protected in case of legal problems or if there is a lawsuit from a third party. This is where a very significant difference between the Encumbrance with power to sell. Object Sales Mortgage bank based power selling basically no problem as long as the sale

${ }^{9}$ M.Bahsan Hukum Jaminan dan Jaminan Kredit Perbankan Indonesia Raja Grafindo Persada 2007 p. 63

${ }^{10}$ Interview with Notary Setiaty Solichah on Wednesday 11 April 2018 his office at Jalan Mutiara office of General Sudirman No. 4 Kab. Stem and Notary Nur Sofati on Tuesday April 172018 located at Jalan Pala West I Bimantara Housing Estate Blok F No. 05 Tegal. 
or the sale price of the object Encumbrance was beneficial to both parties. It was only an issue if the sales or the sale price of the object Encumbrance is below the market price which may harm the interests of the debtor.

Legally authorization by the debtor to the creditor to sell the collateral set forth in the agreement of selling unnecessary power. This is because in a binding agreement guarantees Mortgage has no power of attorney Add Encumbrance (SKMHT) which can be upgraded to the Agreement Granting Mortgage (APHT) as binding guarantees or accecoir containing promises as stated in Article 11 Paragraph (2 ) UUHT No. 4 of 1996 as proof that the security object Encumbrance have been bound in the agreement is the agreement principally accounts payable. If the debtor in default then the lender Mortgage holders in accordance UUHT No.

\section{Conclusion}

Based on the results of research and discussion above it can be concluded;

- Binding of collateral provision of subsidized housing loans at Bank BTN is not done perfectly using the Encumbrance because mortgages subsidized products at Bank BTN included into certain types of credit as set out in Article 12 Regulation of the Minister of Agriculture or the National Land Agency No. 22 of 2017 Concerning Determination Time Limit Use the Power of Attorney Imposing Mortgage to guarantee repayment of certain loans.

- Legal domicile certificate authority against collateral that would sell encumbered encumbrance certificate authority that is used as a final attempt to sell or ultimium remedium, which means the certificate authority to sell used if the debtor is not known to exist, and have done worthily dialing, call in the news media. In the case of the sale of the bank as the lender will appoint a third party as a seller to seek high value, if any excess will be deposited in the District Courts.

\section{References}

[1] Gunarto Suhardi 2003 Usaha Perbankan dalam Perspektif Hukum Yogyakarta: Kanisius.

[2] M.Bahsan Hukum Jaminan dan Jaminan Kredit Perbankan Indonesia Raja Grafindo Persada 2007.

[3] Pieter Latumeten Kebatalan dan Degradasi Kekuatan Bukti Akta Notaris Serta Model Aktanya Makalah Kongres XX Ikatan Notaris Indonesia Surabaya 2009.

[4] Ronny Hanitijo Soemitro Metodologi Penelitian Hukum dan Jurimetri Jakarta Ghalia Indonesia 1990.

[5] Soerjono Soekanto Pengantar Penelitian Hukum Jakarta UI Press 1986

[6] Nikmati KPR Murah di BTN Sejahtera FLPP https://kreditgogo.com/pinjaman/KPRKPA/BTN-Sejahtera-FLPP-KPR.html Accessed Date February 122018

[7] Interview with Mr. Susatyo Isbandono as Head of Consumer Credit Unit on March 12 2018 took place at the BTN Bank Branch Pekalongan Jl. Merdeka No. 7.

[8] Interview with Notary Setiaty Solichah on Wednesday 11 April 2018 his office at Jalan Mutiara office of General Sudirman No. 4 Kab. Stem and Notary Nur Sofati on Tuesday April 172018 located at Jalan Pala West I Bimantara Housing Estate Blok F No. 05 Tegal 